\title{
User-Centered Design and Reference Services in International Librarianship: A Case Study of Nazarbayev University Library
}

\author{
Elizabeth A. King , Heidi E. Dowding \& Julia T. Pflager
}

To cite this article: Elizabeth A. King , Heidi E. Dowding \& Julia T. Pflager (2013) UserCentered Design and Reference Services in International Librarianship: A Case Study of Nazarbayev University Library, Internet Reference Services Quarterly, 18:3-4, 211-226, DOI: 10.1080/10875301.2013.856368

To link to this article: http://dx.doi.org/10.1080/10875301.2013.856368

Published online: 13 Dec 2013.

Submit your article to this journal $\sqsubset$

Џll Article views: 114

Q View related articles $\square$ 


\title{
User-Centered Design and Reference Services in International Librarianship: A Case Study of Nazarbayev University Library
}

\author{
ELIZABETH A. KING \\ Nazarbayev University Library, Patron Services Department, Nazarbayev University, Astana, \\ Republic of Kazakbstan \\ HEIDI E. DOWDING \\ Nazarbayev University Library, Digital Services Department, Nazarbayev University, Astana, \\ Republic of Kazakbstan \\ JULIA T. PFLAGER \\ Nazarbayev University Library, Cataloging \& Acquisitions Department, Nazarbayev \\ University, Astana, Republic of Kazakhstan
}

\begin{abstract}
Major changes over the past decade have moved Kazakhstan and its university students out of the old Soviet model of education and into the realm of international scholarship. While students from this region are being prepared in new and innovative ways, their research needs are still unique and require a firm understanding on the part of academic librarians. With an eye to better serving students at Nazarbayev University, librarians undertook a usability of the library's web resources in February 2013. This article presents findings from the study, which address the distinct needs of university students from post-Soviet nations.
\end{abstract}

KEYWORDS international librarianship, reference services, user experience, usability research, user-centered design, case studies

\section{INTRODUCTION}

Education and research in Kazakhstan has drastically changed over the past 20 years as the country strives to adapt to independence and forge a new

(c) Elizabeth A. King, Heidi E. Dowding and Julia T. Pflager

Address correspondence to Elizabeth A. King, Humanities \& Social Sciences Librarian, Nazarbayev University Library, Patron Services Department, Nazarbayev University, 53 Kabanabay Batyra Avenue, Block 5, Astana, 010000 Republic of Kazakhstan. E-mail: e.a.king4122@gmail.com 
national identity. Under Soviet authority, education focused on preparing students to contribute and fit seamlessly into the larger Soviet system. Suddenly, with the country's independence in 1991, Kazakhstan needed graduates who were prepared to compete in global markets, markets that thrived on very different educational principles than traditional Soviet ones. The past two decades have seen a number of research-oriented institutions established in Kazakhstan, all of which have adopted a more Western educational approach (Nurasheva \& Bondarenko, 2013, p. 7). This educational policy reform in Kazakhstan has drastic implications for the country's library system.

In many ways traditional library services in Kazakhstan were not focused on independent research or access. The concept of user-centered library design is still nascent in library services in Kazakhstan, where all but three libraries still adhere to the model of closed stacks access, a holdover from the Soviet era. Open shelving, where users are allowed to access and browse through the collection, is only beginning to appear in some of the newest research and educational institutions. Such fundamental differences have lasting impacts in the way that students interact with the library. Not only are students and researchers unfamiliar with classifications systems and the benefits of browsing the library's collection, the concept of accessing library holdings or other information online is foreign to a large part of the population. This has huge implications when Kazakhstan's libraries are trying to compete with research and educational standards in the twenty-first century as library websites and digital content become more vital to the reference model employed by Western libraries. The explosion of online journals, databases, and other reference links, not to mention online catalogs, social media, and online librarian reference services make a library's web presence an essential part of modern research and reference (Cohen \& Still, 1999, p. 2). In contrast, a survey conducted in 2010 showed that library websites in Central Asian countries including Kazakhstan had mainly administrative and historical content with very little potential for user interaction or web 2.0 technology (Haneefa \& Venugopal, 2010, p. 99). This survey suggests that, while Kazakhstan has made strides in terms of educational policy and research goals, the country's libraries have not yet fully embraced the concept of independent research and the importance of user-centered design.

In addition to these cultural differences, language plays an important role in the changing reference model in Kazakhstan. Under Soviet rule the Russian language was exclusively used in order to establish a sense of unity and common identity. After independence, Kazakhstan's leaders were faced with a large population of Russian speakers with a desire to simultaneously separate themselves from Russia, create their own national identity, and become globally competitive (Landis, 2012, p. 42). As a result the country now has three national languages: Russian, Kazakh, and English. This trilingual approach adds another layer of complexity to providing reference services in a library setting. 
With ever-increasing globalization and interconnectivity, it is important for academic librarians working within the Western model of North America and Europe to start to consider the research and reference needs of library patrons from different cultural backgrounds. Librarians must understand that users from countries where information is less readily accessible may be unfamiliar with user-centered library models, and that even patrons with the skills to use English-language libraries may not be familiar with traditional Western library services. It is also vital that librarians understand how patrons with different cultural backgrounds than their own may have different needs, in terms of information literacy and reference services, in order to best serve them. Within this article Kazakhstan is an example of this expanding international information-seeking demographic; here we attempt to examine cultural differences and discuss possible solutions for librarians seeking to better serve Central Asian user populations.

\section{Nazarbayev University Library Background}

Nazarbayev University (NU), only in its third year at the time of our study, is quickly becoming a trendsetter in Central Asian research institutions. With more than 100 international faculty members and a rapidly expanding student population, staff have developed resources at a very fast pace to keep up with growth. Currently, the university houses students from the University College London preparatory program, as well as first- and second-year undergraduates. Schools in the university include Engineering, Humanities and Social Sciences, and Science and Technology, but are rapidly growing to include a school of Education as well as graduate degree programs.

The Nazarbayev University Library has an enormous job to fulfill, supporting various languages and the research needs of both local and foreign faculty. The collection is housed on two floors of the library, with a large portion of textbooks being held behind reference/circulation desks. Web services are delivered via an in-house-developed library portal (http://library.nu.edu.kz), based on IBM Websphere, which was first created in 2010. Database subscriptions are generally similar to Western universities, including all of the major vendors. Nazarbayev University Library also utilizes a discovery service, Proquest's Summon, which has become widely used since its implementation in the fall of 2012.

\section{LITERATURE REVIEW}

Studies in Kazakhstani Libraries

As mentioned, the most unique feature of Kazakhstani and other postSoviet nations' libraries is the fact that many still operate under a closed 
stacks model. While this issue is addressed in very little literature available in English, various researchers have explored related issues in the region. In their study of Central and Eastern European libraries, Borgman (1996) noted a "lack of orientation toward self-service" (p. 280) that is similar to that of Kazakhstan; the author discussed how the concept of access does not map to the "Western perspective" (p. 280). This suggests that libraries are still more interested in empowering staff to provide services to users, rather than training users to locate their own materials, a goal emphasized in the Association of College Research Libraries (ACRL) Information Literacy Competency Standards for Higher Education (ACRL, 2000). In their sociological study of reading in Kazakhstan in the mid-1990s, Beisembaeva noted another important facet of post-Soviet Kazakhstani libraries: the collapse of the Soviet Union removed access to other nations' resources, particularly those of Russia (1995, p. 45). The author noted the need for the unification of the country's resources, followed by the need for "participation in the international information systems which already exist" (p. 46).

\section{Studies on Kazakhstani University Students}

Studies on Kazakhstani library users and university students are similarly rare in the English language; however, there is substantial literature available on the development of the education system within the country, which offers great insight in developing a user profile of university students from the area. As Daly noted, Kazakhstan is unique in the region because of its focus on diversification of the education system from the former Soviet model (which emphasized science and math) (as cited in Stein, 2011, p. 3); a large part of this diversification focuses on developing a strong national identity through the teaching of humanities, specifically history and literature (Stein, 2011, p. 3). This suggests that new generations of university students will be unique in the region, but also competitive with students of developed nations (Stein, 2011).

Many Kazakhstani university students are granted the opportunity to go abroad at some point during their studies. According to Zhumagulov, more than 50,000 students have been supported by the government's Bolashak program since 1994 (2012, p. 6). This interest in creating an internationally competitive workforce was also the impetus for the creation of Nazarbayev University, the foremost example of "the country's efforts to put [the] university system on a global footing" (Orynbayev, 2012, p. 11). The limited exposure to the Western library model offered by these programs allows students to gain some basic information literacy skills. However it also makes proper assessment of these students' research knowledge problematic. 
International Students and Challenges to Academic Library Use

Much research on the challenges faced by international students in utilizing Western academic libraries has been carried out over the past 30 years (Amsberry, 2008; Baron \& Strout-Dapaz, 2001; Jackson, 2004; Mu, 2008; SarkodieMensah, 1998). Hughes (2010) suggested that there are three overarching themes that define the challenges faced by international students in terms of effectively using academic libraries, which are "environmental, culturallinguistic, and affective" (p. 3). In terms of environmental challenges, Hughes mentioned the fact that libraries in home countries are often perceived and used differently, for example as "a study hall or textbook repository" (p. 3). The realm of cultural and linguistic challenges is rich with research; most notably Amsberry discussed language as the "primary barrier" for international students in terms of effectively utilizing the academic library (2008, p. 354). In terms of cultural challenges, the issue of mass memorization is notable; Burkhalter and Shegebayev (2012) argued that it is often prized over innovative or critical thinking in international culture, specifically in post-Soviet countries. Hughes' final theme of affective challenges to international students in Western-style universities touches on another widely-studied area of research, which encompasses the issue of library anxiety. While this is felt throughout all academic library populations (Jiao, Onwuegbuzie, \& Lichtenstein, 1996, p. 152), it is exacerbated by the cultural and linguistic challenges faced by international populations (Jiao \& Onwuegbuzie, 1999).

According to Leistman (2000), to best serve the unique needs of international university students, "the perceived and real needs" of each group must "be determined and met proactively" (as quoted in Baron \& StroutDapaz, 2001, p. 315). The specific needs of Asian students are a particular area of study within the broader topic of international academic library users (Hayes and Introna, 2005; Liu \& Winn, 2009; Mu, 2007). Liu and Winn (2009) developed a user profile of Chinese students at the University of Windsor that explores their unique cultural and linguistic challenges in the academic library environment.

\section{METHODOLOGY}

In order to assess the research and reference needs of the student population at Nazarbayev University as well as the library's ability to fulfill those needs, several librarians developed a usability study. A two-part advertising campaign was devised to gather participants and initially included posting fliers, social media advertising, and emailing the student listserv. This campaign failed to gather the amount of participants we determined to comprise an effective sample size (determined to be around 40 , to represent a student body of 1500), so another round of promotions was launched. These 
included engaging faculty, by way of school faculty listservs; they were asked to promote the study in their courses, while emphasizing its voluntary nature. The second campaign was successful, leading to 47 student volunteers.

An initial survey was sent to all volunteer participants. This survey included questions about their educational background and experience with computers and the library. Our response rate was $77 \%$. Upon completion of the survey, students were asked to schedule an individual appointment to meet with a test moderator and carry out the second half of the study. Our response rate for this section was $81 \%$ leaving us with approximately 30 student volunteers. Although a little short of the initial goal, it was still a large enough group to adequately represent the student body of NU.

The tasks of the test (found in Appendix 1 of this article) were designed to rate the successes and failures of the library's online services. The results were then presented to the university's IT department and used in a system redesign (see Appendix 3). The test exemplified many of the issues discussed previously including a general unfamiliarity with the process of finding information without librarian assistance. Furthermore, a few issues arose even within the testing itself.

One of the biggest issues faced was that of the language barrier. The decision was made early on to conduct all testing in English. This was in adherence with the university's policies on language; further, as the library intends to prepare students for international research, utilizing only English allowed us to gain greater insight into the needs of NU students. Although all of the students who attend Nazarbayev University are able to communicate in English, individual aptitude varies widely. In addition, test moderators were at varying levels of English fluency as some were Kazakhstani librarians, while others were American. To address these issues and help maintain a consistent testing experience, the Morae usability testing software was used. This program allowed the students to move through the test at their own pace. Each task appeared onscreen where the student could read and reread if need be, and removed the need for the moderators to read the task out loud. Morae also recorded each session, which allowed for greater inspection. By conducting the test in this way we were able to closely replicate testing sessions for each student and gain reliable, useful information from the study.

The portal changes made after the results were submitted to the IT department are an important first step in addressing the reference needs of this particular community. Hopefully it will lead to a greater understanding, appreciation, and further development of the library and its services for the student population. By publishing the results and main themes of the study, which appear in the following sections, it is hoped that research on the information needs of international library patrons will be furthered. 


\section{Participant Profile}

All students at Nazarbayev University to date are citizens of Kazakhstan. In order to be accepted to Nazarbayev University, students must achieve minimum scores on state-mandated standardized tests, as well as on the TOEFL exam; that is, all students are relatively proficient in English, but none are native speakers. In order to bring students up to date on utilizing an academic library, one instruction session is mandatory for students of the Center for Preparatory Studies, so every student has had at least minimal experience with the collections and e-resources.

Twenty-three students participated in the usability study, which also included an introductory survey designed to gather demographic information. From the survey it was learned that the majority were enrolled in the School of Science and Technology (11), while the rest were evenly distributed among the School of Humanities and Social Sciences (3), the Center for Preparatory Studies (CPS), (4), and the School of Engineering (5). The majority of students in the study were in the second year of their Bachelor's degree studies (11), while eight were first year Bachelor's degree students, and four were CPS students.

\section{Current Library Use}

The survey showed that there was relatively little correlation between which school and year of study students were enrolled in versus library use. Library visit rates were fairly evenly spread between high (11 or more visits per month) and low (less than five), with no discernible differences in school or year. Likewise, students who reported going to the library 11 or more times per month reported varying rates of library website use in looking for information.

The greatest use of the library website reported was in doing online research (databases and other online resources), with 18 (78\%) reporting such usage. Searching for books was next with 11 (48\%) reporting such usage. Other reported usage included looking for information about the library itself, such as opening hours, and looking up student account information. Remarkably, however, only one student reported using the library to look up student account information, all students who participated in the study successfully navigated both tasks that directly involved their student accounts-logging in with student ID and password, and renewing a checked-out book. Possible explanations for this disparity include the requirement of all students to attend a library orientation session in which logging on and checking student accounts is taught, and the fact that in order to access subscription databases students are required to be signed in. 


\section{Language and Cultural Barriers}

As mentioned previously, all students are required to earn a minimum score on the TOEFL exam both in order to enter the CPS program and in order to enroll in the Bachelor's degree program; however this still often means that students come to NU with only a few years of English study, and possibly one year of high school-level study abroad in an English-speaking environment. A common reference question that NU Library librarians encounter is how to find books to improve English language skills, particularly pronunciation and writing, within a particular field.

Although students have the proficiency to communicate conversationally in English, they still struggle with college-level discussion and writing skills; library jargon presents a challenge. In the prestudy survey, two students selected conflicting answers in regards to their use of the "library portal," suggesting that students may still struggle with basic library terminology, much less more esoteric terms like "Boolean operators" and "limiters." This assumption is backed up by circulation transactions in which students use terms that, while getting the point across, are not the commonly used "check out," "renew," or even "return" that patrons in the United States generally use without thinking.

Study participants also showed a lack of understanding of the difference between various electronic resources offered by the library. In part this is likely caused by language barriers and specific terminology, but students often grouped together e-resources searchable in the library's subscription databases and e-books in the online library catalog. When asked to search for an e-book about a specific subject, five students started their search by clicking on the button labeled 'E-resources' in the main search box on the homepage. Instead of searching the library catalog, this option only searches subscription databases, leading students to either give up or start over in their search.

\section{EXPERIENCES AND PERCEPTIONS OF LIBRARIES IN KAZAKHSTAN}

Fifteen students (65\%) reported visiting the library more than five times per month, and 22 (96\%) reported visiting at least three times per month, yet only $12(52 \%)$ reported using the library website to search for information about books and other print resources. By themselves these numbers are not overly significant since the library is commonly used as a quiet study area by students around the globe; however, combined with results from the usability study, it becomes apparent that students are not used to-at times not even interested in-finding library books on their own. In the second task of the study, which required students to find a specific title in the catalog and produce information about the number and location of copies owned by the 
library, only about $44 \%$ of students were able to complete all parts of the task. Of the approximately $42 \%$ of students who only partially completed the task, the majority did not know how to manipulate the catalog to determine shelf location, and when asked what they would do next to solve the problem, the most common answer was "ask a librarian." The task of finding a book in the catalog and going to its location on the shelf-generally considered routine in the United States and United Kingdom-is still not perceived as either permissible or simpler than asking a librarian.

Student responses to difficult tasks during the usability study revealed aspects of the cultural attitude toward libraries in Kazakhstan and other Commonwealth of Independent States (CIS) countries as discussed in the previous section. When faced with a task requiring that they find a DVD using the library website, three students mentioned a list of DVDs that was emailed to all students when they were first accessioned; one student knew the physical location of the DVDs in the library but did not know how to find information about them via the library website. Perhaps directly relating to the lack of open-stacks libraries in CIS countries, students displayed an incomplete understanding of the library catalog and what it contained. The task asking students to find a DVD did not specifically instruct them to search the library catalog for a DVD, leaving students to make that connection-or not-for themselves. Consequently, nearly $20 \%$ of participants failed to complete the task because they did not use the library catalog.

The rates at which students responded to difficulty in task completion by saying they would ask a librarian, or in which they judged themselves finished with a task even though they admitted there were parts they did not know how to complete, speaks to a general expectation that the library website does not need to be particularly easy to use or educational for patrons. Many seemed content with the fact that librarians were able to use these tools, and could be relied upon to provide assistance when needed. Students were very good at completing tasks in which they had been specifically trained-logging in, renewing a book, even searching subscription databases-but had difficulty in locating or producing new information. One participant even stated, upon having difficulty in locating the contact information for a subject librarian, that it is "easier to just ask."

The ramifications of these attitudes among students can be felt throughout the library, but reference services and information literacy instructors bear the brunt of responsibility for working within this system, even though they may have very little input in how information resources and their accompanying finding aids are structured. Knowing more about how students view the information-seeking process, instructors can design their sessions to more clearly articulate library and faculty expectations of student research practices. When students do come to the reference desk to find information, librarians can use these one-on-one opportunities to help 
students interact with the library website, rather than simply handing out information. This, of course, is a practice that reference librarians at NU Library have already been working toward; however having a better idea of student attitudes will help them use their interview to probe deeper into the specific motivations of students they encounter and therefore ascertain more clearly what actual difficulties exist versus what is simply symptomatic of a cultural attitude toward research and student expectations of the library.

For these reasons, it was extremely important to librarians managing this study to include reference librarians as volunteer moderators for the usability study, and to provide a detailed report to all library staff as to study findings. Having first-hand experience of student difficulties will enable reference librarians and information literacy instructors to consider these issues in advance of interactions with students, and be able to develop appropriate interview and instruction strategies.

Student behaviors during the usability study also revealed a certain impact of philosophies of rote memorization and collective intellectual property, described previously, on student information-seeking behaviors. Students did not always feel compelled to use critical thinking skills to find an answer during tasks, instead indicating that they would rely on the knowledge of others to accomplish goals-most often librarians-a circumstance that indicates the need for more orientation and information literacy instruction time spent on the importance of intellectual honesty and the use of critical thinking within the research process. Although the results of incomplete intellectual honesty among students in former Soviet states may be the same as those among Western students-plagiarism-the reasons can be markedly different, an important consideration for all librarians working in the university library setting among often increasingly international student populations.

\section{Understanding of Library Terminology}

As previously mentioned, students showed a lack of understanding of library terminology. This issue is symptomatic of both the English language barrier and prevailing attitudes toward libraries in Kazakhstan and former Soviet countries in general. As discussed, students had difficulty finding information about a book's physical location. Almost no students referenced the call number as being useful in ascertaining this information, while at least two thought that the ISBN would be helpful. Tasks two, three, and five revealed the most about students' understanding of search terminology, and points to an almost complete lack of exposure to self-directed library research. When asked to locate books by the title Great Expectations and about World War II respectively, a majority of students either chose to search by keyword or did 
not make any field choice, defaulting to a keyword search. Only four (17\%) chose to search Great Expectations by title. No students chose to search for books about World War II using the Subject Terms field.

Task five, which specifically instructed students to search using certain fields, saw similar results. When instructed to search for the subject heading "cell biology" students most often chose either keyword or title for their field. When asked to find a specific title published in a particular year, many students either had trouble figuring out how to filter by year, or simply searched for the title (not always in the title field), and tried to scan through the results to determine the number published in the year asked for.

Taking into account students' relative lack of experience searching library online catalogs and their unfamiliarity with library search terminology, reference librarians and information literacy instructors can again better tailor reference interviews and instruction sessions to the known needs of students. Approaching this user group with a better understanding of cultural and language differences can have direct correlations to providing patrons with services they can understand and use. Findings from this section of our study were discussed with the Reference Services department within the library, and decisions were made to adapt instruction sessions and menu language within the library portal in order to make information more digestible for students.

\section{CONCLUSION}

Globalization, the emergence of new nations, and the evolution of existing education systems provides exciting opportunities and challenges for library professionals around the world. People from countries like Kazakhstan in Central Asia are increasingly taking part in global scholarship and business and thus need to be effective information seekers. As education and research continues to experience a shift toward globalization, it is important for reference and instruction librarians to keep pace with the needs of increasingly international user populations. This study of usability in one Kazakhstani academic library seeks to add to librarian understandings of the motivations of student information seekers and their perceptions of the library in research and education.

\section{REFERENCES}

Amsberry, D. (2008). Talking the talk: Library classroom communication and international students. The Journal of Academic Librarianship, 34(4), $354-357$. 
Association of College \& Research Libraries. (2000). Information literacy competency standards for higher education. Chicago: Author. Retrieved from http://www.ala.org/acrl/standards/informationliteracycompetency.

Baron, S., \& Strout-Dapaz, A. (2001). Communicating with and empowering international students with a library skills set. Reference Services Review, 29(4), 314-326.

Beisembaeva, Z. A. (1995). Reading in Kazakhstan. International Information and Library Review, 27, 37-46.

Borgman, C. L. (1996). Automation is the answer, but what is the question? Progress and prospects for Central and Eastern European libraries. Journal of Documentation, 52(3), 252-295.

Burkhalter, N., \& Shegebayev, M. R. (2012). Critical thinking as culture: Teaching post-soviet teachers in Kazakhstan. International Review of Education, 58, 55-72. doi:10.1007/s11159-012-9285-5.

Cohen, L. B., \& Still, J. M. (1999). A comparison of research university and two year college library websites. College and Research Libraries, 60(3), 275-289.

Haneefa, K., \& Venugopal, A. M. K. (2010). Contents of national library websites in Asia: An analysis. Annals of Library and Information Studies, 57(2), 98-108.

Hayes, N., \& Introna, L. (2005). Cultural values, plagiarism, and fairness: When plagiarism gets in the way of learning. Ethics \& Behavior, 15(3), 213-231.

Hughes, H. (2010). International students' experiences of university libraries and librarians. Australian Academic \& Research Libraries, 41(2), 77-89.

Jackson, P. A. (2004). Incoming international students and the library: A survey. Reference Services Review, 33(2), 197-209. doi:10.1108/00907320510597408.

Jiao, Q. G., Onwuegbuzie, A. J., \& Lichtenstein, A. (1996). Library anxiety: Characteristics of at-risk college students. Library and Information Science Research, $18,151-163$.

Jiao, Q. G., \& Onwuegbuzie, A. J. (1999). Library anxiety among international students. Retrieved from http://eric.ed.gov/PDFS/ED437973.pdf.

Landis, D. (2012) Language and literacy education in twenty-first century Kazakhstan. Retrieved from http://enu.kz/repository/repository2012/Language-andLiteracy.pdf.

Liestman, D. (2000). Reference services to the international adult learner. Reference Librarian, 33(69/70), 363-377. doi: 10.1300/J120v33n69-32

Liu, G. \& Winn, D. (2009). Chinese graduate students and the Canadian academiclibrary: A user study at the University of Windsor. Retrieved from http://scholar .uwindsor.ca/cgi/viewcontent.cgi?article $=1005 \&$ context=leddylibrarypub.

$\mathrm{Mu}, \mathrm{C}$. (2007). Marketing academic library resources and information services to international students from Asia. Reference Services Review, 35(4), 571-583. doi:10.1108/00907320710838390.

Nurasheva, K., \& Bondarenko, V. (2013). New landmarks in building qualitative education in Kazakhstan. In M. Stiashy \& T. Gore (Eds.), Going global: Identifying trends and drivers of international education (pp. 5-16). Bingley, UK: Emerald Group. 
Orynbayev, Y. (2012). Education reforms in Kazakhstan. In T. Reagan \& A. Sagintayeva (Eds.), Proceedings from Eurasian Higher Education Leaders Forum (pp. 10-11). Astana, KZ: Indigo Print. Retrieved from http://files.eric.ed.gov/ fulltext/ED541898.pdf.

Sarkodie-Mensah, K. (1998). International students in the U.S.: Trends, cultural adjustments, and solutions for a better experience. Journal of Education for Library and Information Science, 39(3), 214-222.

Stein, M. (2011). Connecting to the Khans: Shaping national identity of the next generation through education in Kazakhstan. Current Issues in Education, 14(2), $1-11$.

Zhumagulov, B. (2012). Educational policy achievements in Kazakhstan. In T. Reagan \& A. Sagintayeva (Eds.), Proceedings from Eurasian Higher Education Leaders Forum (pp. 5-9). Astana, KZ: Indigo Print. Retrieved from http://files.eric.ed.gov/fulltext/ED541898.pdf.

\section{APPENDIX 1: TASK LIST}

1. Go to the library portal and log in with (specified) username and password.

a. Tell us what features stand out to you as important or interesting.

2. Imagine you are looking for a good book to read in English. Find the book Great Expectations by Charles Dickens in the library catalog.

a. How many total copies does the library own?

b. Where would you look for information about where the book is located in the library?

3. Imagine that you are doing a research project about World War II

a. Search for books about World War II.

b. You have found one that looks interesting, but don't have enough time to go to the library and get it. You decide to order an electronic copy. How would you go about doing it? Please tell us when you're finished ordering.

4. Now you're very interested in World War II, and you've heard that the library has DVDs you can borrow. Find a DVD about World War II.

5. Let's say it's the beginning of the semester and you want to find information about your textbooks. You know you need two books that have to do with cell biology and calculus. Please look for them in the following ways:

a. Search for all items with the subject heading "cell biology."

b. Find items with the title Calculus that were published in 2010 .

c. Use the advanced search to find Calculus, by James Stewart.

d. Use the advanced search to find items that have "cell biology" in their titles. 
6. You'd like to read more about chemistry, but don't want to go to the library to get a book.

a. Try to find an electronic book related to chemistry.

b. Go to page 30 of the book and tell us what it's about.

7. Imagine that one of your teachers has assigned a research paper about cancer, and said you can find a lot of good information in the INFORMS Journal database.

a. Start by going to the INFORMS database.

b. Find a full-text article on cancer.

c. Now, since you're here and you've been meaning to look it up anyway, look for an article on astronomy. Make sure it's an article that includes an abstract.

8. You just remembered that one of the books you borrowed is almost due.

a. Go to your student account from the library portal.

b. Renew the book that is almost due.

c. By what date should this book be returned to the library after you renew it?

9. Now let's imagine that you need some more help using the library portal

a. You found some good articles on cancer, but your professor says you need more. Locate the email address of one or both of the subject librarians for your school.

b. You are having an issue with your library account, but are not able to visit the library. Contact someone in order to get help. The message should say: "I returned a book, but it is still checked out to my account. Please help me to resolve this issue." 


\section{APPENDIX 2: FIGURES}

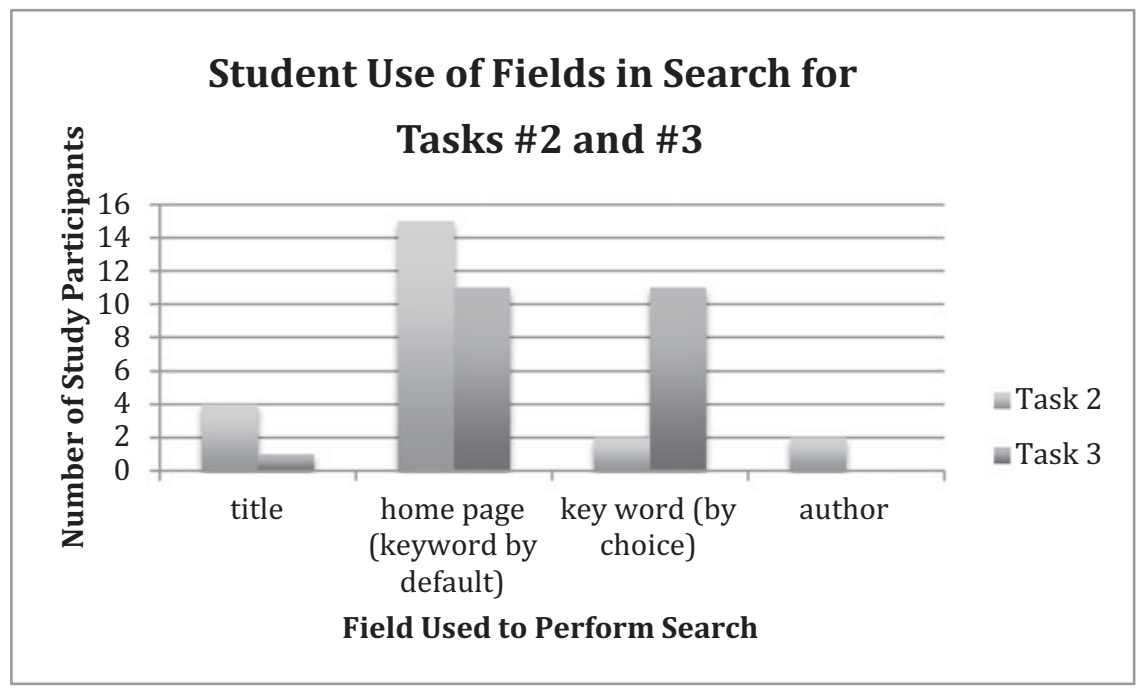

FIGURE 1 Student searches in Tasks 2 and 3, which asked for a specific title and subject, respectively, revealed much about the lack of understanding of library terminology.

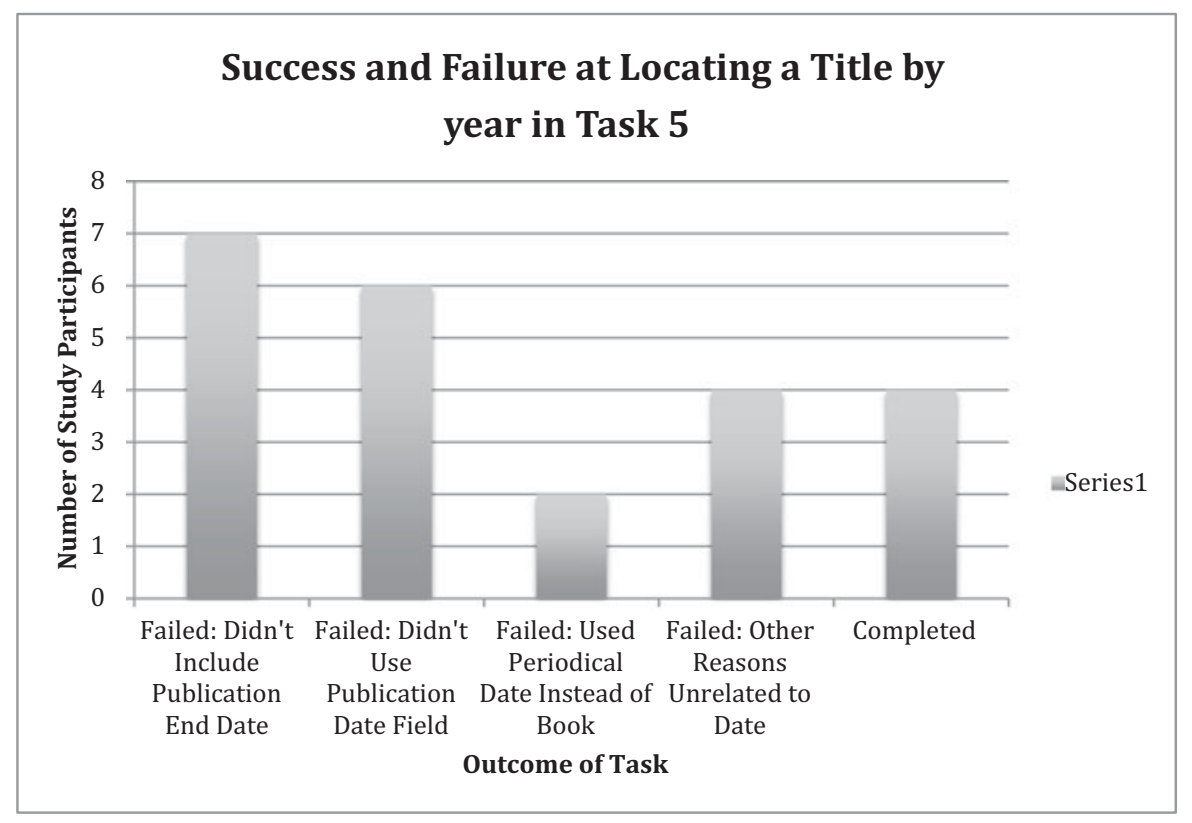

FIGURE 2 When asked to find a specific title published in a particular year, only four students successfully utilized the date field to narrow their results properly to only books which fit those criteria. 


\section{APPENDIX 3: SUGGESTIONS LIST PRESENTED TO WEB PORTAL DEVELOPERS}

\section{Online Catalog Search and Results Pages}

- Clarify language and layout of results page

o Important information should be prominent: call number, availability, format

- Revise icons to be more universal/understandable; remove icons that students don't need/can't use, like "download machine readable entry"

- Remove as many steps as possible from performing multiple searches (e.g., remove the New Search button, because students use the browser's back button)

- Ability to sort results page

- Make items that are links more obvious (like e-book link)

- Clarify language of "search in catalogues" filter so it is more obvious what each check box will search in

- Advanced Search: remove "search from this word/search including this word" as it causes too many problems for users; allow Boolean (AND, OR, NOT) between fields

- Better and more obvious help links for using all search options

\section{Library Homepage}

- Fix the main search box to better differentiate between Summon and the library catalog

- Tabs to different types of search OR

- Links to different types of search

- Pare down top menu to be more basic/more intuitive

- Include Information Literacy everywhere

- Define or explain everything in simple and intuitive ways

- Offer a FAQ section (update old FAQ menu option)

\section{Library Services}

- Revise the Electronic Document Delivery system to be more effective

- Place Libguides in a more conspicuous, better explained area (e.g., Research by Subject)

- Make Ask-A-Librarian page more attractive and easier to browse

- Reorganize e-resource database page so that users have to scroll less - browse by subject, or

o click on alphabetical links for title 